\title{
VARIATION IN STOMATAL NUMBERS OF GLOSSOPTERIS LEAVES FROM THE LOWER PERMIAN OF PARANÁ BASIN, BRAZIL
}

\author{
ISABELA DEGANI SCHMIDT \& MARGOT GUERRA SOMMER \\ Instituto de Geociências, UFRGS, Av. Bento Gonçalves, 9500, Cx.P. 15001, 91501-970, Porto Alegre, RS, Brasil. \\ degani.schmidt@ufrgs.br,margot.sommer@ufrgs.br \\ MARY ELIZABETH C. BERNARDES DE OLIVEIRA \\ Programa de Pos-graduação em Geoquímica e Geotectônica, IGc, USP, Cidade Universitária, 05508-080, \\ São Paulo, SP, Brasil.maryliz@usp.br
}

\begin{abstract}
The stomatal density and index in compressed leaves of Glossopteris communis from two different roof shales from the Lower Permian in Paraná Basin, Brazil (Western Gondwana) have been investigated to test the possible relationship with modeled global changes in atmospheric $\mathrm{CO}_{2}$ during the Phanerozoic. The obtained parameters show that the genus Glossopteris from the Cool Temperate biome can be used as $\mathrm{CO}_{2}$-proxy, despite the impossibility of being compared with living relatives or equivalents. When confronted with already published data for the Tropical Summer Wet biome, the present results confirm the detection of low levels of atmospheric $\mathrm{CO}_{2}$ during the Early Permian, as predicted by the modeled curve. Nevertheless, the lower stomatal numbers detected at the climax of the coal interval (Faxinal Coalfield, Sakmarian) when compared to the higher ones obtained in leaves from a younger interval (Figueira Coalfield, Artinskian) could be attributed to temporarily high levels of atmospheric $\mathrm{CO}_{2}$. Therefore, the occurrence of an extensive peat generating event at the southern part of the basin and subsequent greenhouse gases emissions from this environment may have been enough to reverse regionally and temporarily the reduction trend in atmospheric $\mathrm{CO}_{2}$. Additionally, the Faxinal flora is preserved in a tonstein layer, which is a record of volcanic activity that could also cause a rise in atmospheric $\mathrm{CO}_{2}$. During the Artinskian, the scarce generation of peat mires, as revealed by the occurrence of thin and discontinuous coal layers, and the lack of volcanism evidence would be insufficient to affect the general low $\mathrm{CO}_{2}$ trend.
\end{abstract}

Key words: paleo- $\mathrm{CO}_{2}$ proxy, pteridosperms, fossil cuticles, Rio Bonito Formation, peat-forming floras, Gondwana.

RESUMO - Frequências estomáticas foram calculadas em cutículas de Glossopteris communis, procedentes de dois afloramentos do Permiano Inferior na bacia do Paraná, com o objetivo de relacioná-las com variações na concentração atmosférica de $\mathrm{CO}_{2}$ modeladas para o Fanerozoico. Os resultados indicam que as glossopterídeas do bioma Temperado Frio podem ser utilizadas como equivalentes climáticos para inferência de níveis de $\mathrm{CO}_{2}$ paleoatmosférico, apesar da impossibilidade de estabelecer um equivalente ecológico atual. Quando confrontados com dados obtidos para o bioma Tropical de Verão Úmido, os resultados aqui apresentados confirmam a detecção de baixos níveis de $\mathrm{CO}_{2}$ na atmosfera durante o período, de acordo com o modelamento da curva. Porém, as frequências estomáticas mais baixas detectadas no clímax do intervalo formador de carvão (jazida de Faxinal, Sakmariano), quando comparadas às frequências mais altas obtidas nas folhas de intervalo mais jovem (jazida de Figueira, Artinskiano), poderiam ser atribuídas a níveis temporariamente altos de $\mathrm{CO}_{2}$ na atmosfera. A ocorrência de extenso evento gerador de turfa na parte sul da bacia, com a consequente emissão de gases-estufa deste ambiente, poderia ter sido suficiente para reverter a tendência de queda de $\mathrm{CO}_{2}$ atmosférico em âmbito regional ainda que de forma temporária. Além disso, a flora de Faxinal está preservada em uma camada de tonstein, registro de atividade vulcânica que poderia ter afetado os níveis de $\mathrm{CO}_{2}$. No Artinskiano, a formação de turfeiras em menor escala, evidenciada por camadas de carvão descontínuas e delgadas, sem registro de vulcanismo, teria sido insuficiente para afetar a tendência de baixo $\mathrm{CO}_{2}$.

Palavras-chave: equivalente paleoclimático para $\mathrm{CO}_{2}$, pteridospermas, cutículas fósseis, Formação Rio Bonito, floras formadoras de turfa, Gondwana.

\section{INTRODUCTION}

The applicability of fossil plant leaves as biosensors of Earth's paleoatmospheric $\mathrm{CO}_{2}$ fluctuations is being increasingly ratified through the comparisons between the stomatal numbers (stomatal density and index) of fossil, living and herbarium material (McElwain, 1998; Kouwenberg et al., 2003; Wagner et al., 2005) since Woodward (1987) observed an inverse correlation between stomatal frequency in extant plants and the concentration of atmospheric $\mathrm{CO}_{2}$. Even 
though earlier studies were focused on historical and recent pre-historical approaches (Beerling \& Chaloner, 1992, 1993; Kürschner et al., 1996), this method has encouragingly been applied to cuticular analyses of leaves from different geological intervals, from the Early Devonian through the Holocene (Van der Burgh et al., 1993; McElwain \& Chaloner, 1995, 1996; Kürschner et al., 1998; McElwain et al., 1999; Beerling, 2002). In general, the estimated results based on stomatal parameters help to calibrate the curve of Phanerozoic levels of paleoatmospheric $\mathrm{CO}_{2}$ calculated by the GEOCARB model (Berner, 1991, 1994; Berner \& Kothavala, 2001).

Different authors pointed out that environmental factors such as temperature and humidity can influence stomatal density by altering the size and/or spacing of the epidermal cells (Salisbury, 1927; Tichá, 1982; Roth-Nebelsick, 2005). However, atmospheric $\mathrm{CO}_{2}$ is the main factor that influences the development of stomata from epidermal cell initials, thus directly affecting the number of stomatal pores on the leaf surface. Calculation of the stomatal index, which is a ratio of the number of stomatal cells to the total number of cells (epidermal and stomatal) on the leaf surface, separates the direct effects of atmospheric $\mathrm{CO}_{2}$ from the indirect effects of all other environmental parameters on stomatal numbers (McElwain, 2003). Therefore the stomatal index is a much more stable parameter and recent data ratify it as being amongst the most robust proxies for paleoatmospheric $\mathrm{CO}_{2}$ (Royer et al., 2001a; Beerling et al., 2009).

When dealing with Mesozoic and Cenozoic floras, results from fossils have been compared with close living relatives (McElwain et al., 1999; Chen et al., 2001; Royer et al., 2001b), called nearest living relative (NLR) species (Mosbrugger, 1999). The method is based on the premise that climatic tolerances of the fossils would be similar to those of their NLR (Taylor et al., 2009).

In an attempt to overcome the difficulties of identifying taxonomic affinities between extinct and extant forms in large time spans (i.e. Paleozoic to Recent), comparisons have been made between fossil and nearest living equivalent (NLE) species. These are, as far as possible, species from the present day of comparable ecological setting and/or structural similarity to their fossil counterparts (McElwain \& Chaloner, 1995). However, it is not always possible to find living matches to extinct plant species.

Cleal et al. (1999) presented an alternative approach to this problem focusing on the foliage of a single species, viz. Neuropteris ovata Hoffmann, a Paleozoic pteridosperm (Medullosales) from the Equatorial swamp forest, to test whether its stomatal frequencies work as $\mathrm{CO}_{2}$-proxies at different stratigraphic levels during the Upper Carboniferous. They observed a marked drop in stomatal density (SD) and stomatal index (SI) in the very Early Stephanian that could reflect a rise in paleoatmospheric $\mathrm{CO}_{2}$ due to a drastic contraction of tropical forests.

The results obtained by Retallack (2001) for atmospheric $\mathrm{CO}_{2}$ through SI values in herbarium and fossil leaves of Ginkgo since late Triassic and Paleozoic pteridosperms (Lepidopteris, Tatarina and Rachyphyllum) as $\mathrm{CO}_{2}$ proxies, agreed partially with the geochemical models proposed for comparison by the author. A transfer function, in which stomatal parameters of extant species calibrated against $\mathrm{CO}_{2}$ are replaced by those of fossil species (Roth-Nebelsick, 2005), available for Ginkgo was applied to the stomatal measurements in the pteridosperms in order to calculate the corresponding atmospheric $\mathrm{CO}_{2}$ levels.

Vörding \& Kerp (2008) analyzed cuticles of the Upper Permian pteridosperm species Peltaspermum martinsii (Germar) Poort \& Kerp from different coeval outcrops in the Southern Alps to test its applicability as a paleo- $\mathrm{CO}_{2}$ proxy. The authors also employed a transfer function previously determined for Ginkgo leaves in order to establish comparisons with the atmospheric $\mathrm{CO}_{2}$ models. Their estimates for the paleoatmospheric $\mathrm{CO}_{2}$ levels resulted much higher than those of the geochemical models. Stomatal parameters were considered by the authors as speculative due to the use of a transfer function which has been established for a distinct taxon.

Vörding et al. (2009) tested stomatal parameters of a pteridosperm, Odontopteris brardii (Brongniart) Sternberg, from two geologically and ecologically different localities in Europe (Germany and France) in the late Stephanian. Similar values found in all specimens suggested that habitat-specific factors did not significantly affect SI. The results inferred from the SI values, despite being a little lower than the ones from the paleoatmospheric $\mathrm{CO}_{2}$ models used for comparison, still corroborate the hypothesis of low levels of the gas during the late Paleozoic.

However, the determination of species which could be modern analogues to the extinct group of pteridosperms, abundant in the fossil record and often with well preserved cuticles, still remains an unresolved matter.

\section{The Glossopteris Flora}

In the Gondwanan realm, the Phylum Pteridospermophyta (Taylor et al., 2009) was mainly represented by the Glossopteridales, which dominated the flora during the Permian (Gastaldo et al., 1996). The plants of this group were prominent elements of temperate ecosystems, primarily those of wetlands, and a swampy habitat has been inferred by their dominance in taphofloras which have been recovered mainly from strata associated with Permian Gondwana peat and coals (Anderson \& Anderson, 1985; Pigg, 1990; Guerra-Sommer et al., 1991; Pigg \& McLoughlin, 1997; Banerjee, 2005). Nevertheless, fossil remains are known from fluvial and lacustrine deposits as well (Archangelsky et al., 1996; Srivastava, 1997; Prevec et al., 2009, 2010; Holz et al., 2010), suggesting that this group of plants could also occur at wetter areas of seasonally dry environments.

Over 200 morphospecies of the genus Glossopteris have been described from the Permian rocks of the Gondwanaland countries, viz. Africa, Antarctica, Australia, India and South America (Stewart \& Rothwell, 1993), many of them are based exclusively on the macromorpholgy of the impression leaves. Epidermal features of leaf adpressions have been used to distinguish a number of Glossopteris species in material recovered mainly from roof shale levels (Pant \& Gupta, 1968, 1971; Pant \& Singh, 1971; Guerra-Sommer, 1992).

In Brazilian Gondwana, abundant and well preserved 
Glossopteris compressed leaves have been described from muddy and silty sand layers interbedded with coal seams in coalfields in the northeastern and southern areas of the coal bearing Rio Bonito Formation from the Lower Permian of the Paraná Basin. Glossopteris leaves are also known from older glaciocontinental facies of the Itararé Group (Asselian to Sakmarian) and younger geologic strata of Irati, Teresina and Rio do Rasto formations (Late Artinskian to Wuchiapingian), however they are in the form of impressions only (GuerraSommer \& Cazzulo-Klepzig, 2000).

The present study is based on the compression leaves of Glossopteris communis Feistmantel, collected from the roof shale sediments of the Rio Bonito Formation exposed in Figueira Coalfield, in the northeastern, and Faxinal Coalfield, in the southern Paraná Basin. Besides their macromorphology, the similar epidermal features among the Glossopteris leaves allowed us to consider them as a single biological entity. The use of a single taxon from a specific habitat (peat swamps in the present study) is an important requirement when comparing the effects of altered atmospheric $\mathrm{CO}_{2}$ regimes on parameters like stomatal frequency (Cleal et al., 1999).

The aim of this study is (i) to test whether cuticles of the extinct Gondwanan taxon Glossopteris communis are suitable as proxies for $\mathrm{CO}_{2}$ concentrations in the paleoatmosphere, and (ii) to find lines of evidence to support the inferences from the obtained stomatal patterns.

\section{GEOLOGICAL AND PALEBOTANICAL SYNTHESIS}

The Paraná Basin is a large $\left(1.4 .10^{6} \mathrm{~km}^{2}\right)$ intracratonic sag basin covering part of southern Brazil, Paraguay, Uruguay and Argentina (Figure 1). Basin floor subsidence, in addition to Paleozoic sea-level changes, created six second-order

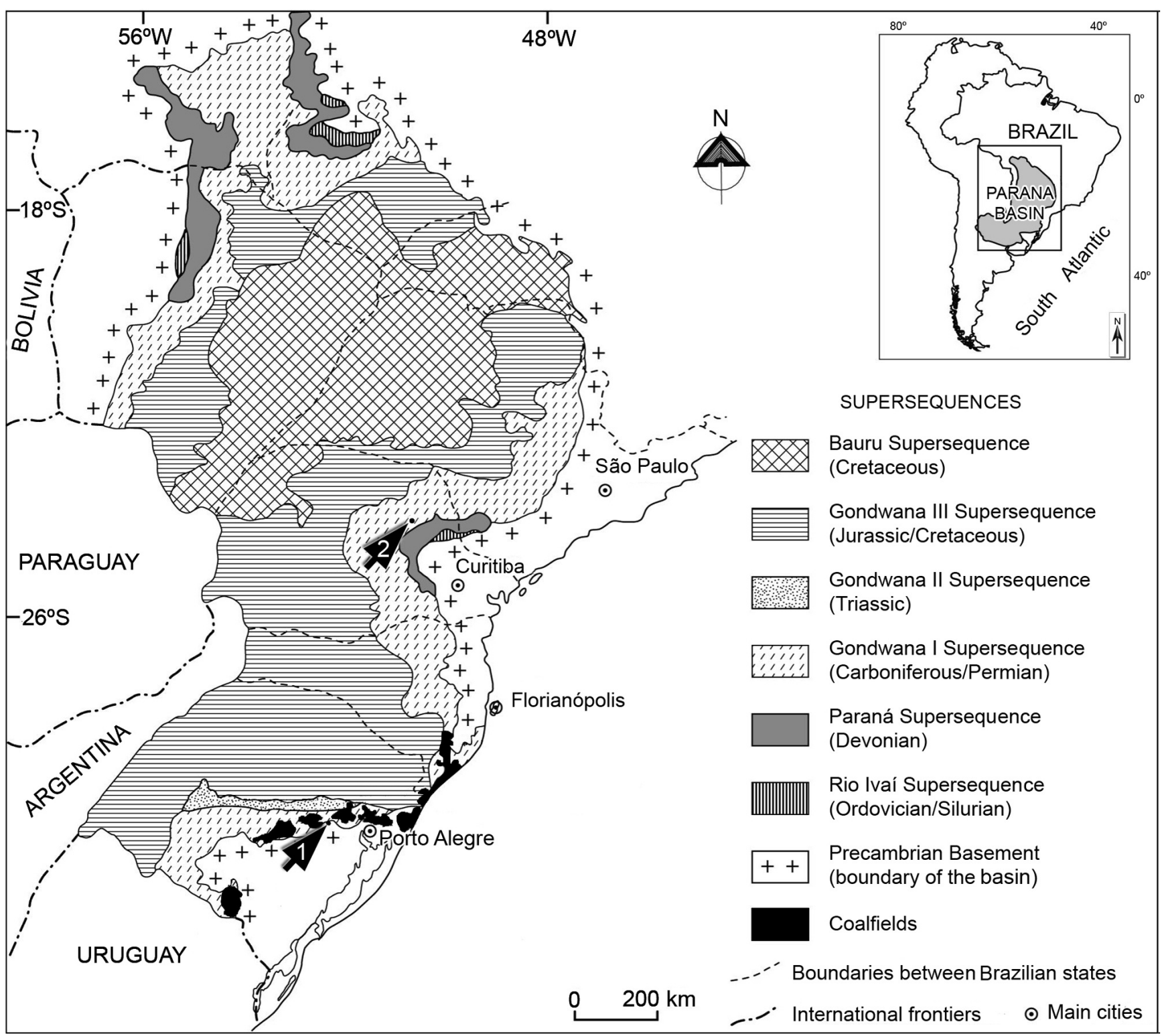

Figure 1. Schematic geological map showing the main supersequences of the Paraná Basin (modified from Santos et al., 2006). Coalfields are represented according to Horbach et al. (1986). Faxinal Coalfield is indicated by arrow 1 and Figueira Coalfield by arrow 2. 
sequences deposited from the Ordovician to Late Cretaceous, separated by regional unconformities (Milani, 1997). The coal-bearing Rio Bonito Formation, which is the subject of this study, occurs at the base of the second order Carboniferous-Early Triassic sequence (Gondwana I Supersequence). Extensive peat swamps developed during the deposition of Rio Bonito Formation in Paraná Basin at a paleolatitude of approximately $50^{\circ} \mathrm{S}$, included in the Cool Temperate biome (Rees et al., 2002).

The study area comprises the Faxinal Coalfield, in the southeastern outcrop belt of the Rio Bonito Formation in southern Brazil, Rio Grande do Sul State, and the Figueira Coalfield, located in the eastern area of the Brazilian portion of the basin in Paraná State (Figure 1).

The Faxinal Coalfield, mined by the Companhia de Pesquisas e Lavras Minerais - COPELMI, is located near the town of Arroio dos Ratos, about $120 \mathrm{~km}$ west of Porto Alegre, Rio Grande do Sul State. The Faxinal coal succession includes five coal seams, named I, IM, M, MS and S from the base to the top of the sequence. The present study focuses on a fossiliferous argillite approximately $7 \mathrm{~cm}$ thick, interbedded with the upper coal seam (S). Petrographic studies in this argillite reveal a volcanic ash-fall origin for this sediment, thus identifying it as a tonstein (Guerra-Sommer et al., 2008a). Ion microprobe (SHRIMP II) dating of zircons from the tonstein by Guerra-Sommer et al. (2008b) yielded an age of $290.6 \pm 1.5 \mathrm{Ma}$ (Sakmarian).

According to Simas (2008), the original thickness of the unconsolidated ash has been inferred at about $28 \mathrm{~cm}$. This evidence suggests the existence of an active and widespread explosive volcanic event in the Lower Permian of Western Gondwana. Volcanic activities in the surrounding areas have been assumed as ignition sources for wildfires, which produced large amounts of charcoal at the basal level of the tonstein layer (Jasper et al., 2009).

The compression taphoflora preserved in the Faxinal tonstein is predominantly gymnospermous (Guerra-Sommer, 1992), consisting of glossopterid fragments that constitute about $70 \%$ of the entire assemblage. Taxa identified include Glossopteris brasiliensis Guerra-Sommer, G. papillosa Guerra-Sommer, G. similis-intermittens Guerra-Sommer, Plumsteadia semnes Rigby and Platycardia sp. Cordaitalean taxon Rufloria gondwanensis Guerra-Sommer and Sphenopteris cf. ischanovensis are subdominant elements (Guerra-Sommer, 1988).

Palynological analyses of the Faxinal coals indicate the dominance of bisaccate (striate and non-striate) and monosaccate pollen grains related to glossopterids, conifers and cordaitaleans (Cazzulo-Klepzig et al., 2007). These pollen grains are followed by a low proportion of spores of lycopsids, filicopsids and scarce sphenopsids which emphasizes the minor contribution of pteridophytic plants to the peat-coal forming vegetation (Cazzulo-Klepzig et al., 2009).

The stratigraphic analyses conducted by Schneider et al. (1974) in the states of Santa Catarina and Paraná defined three members for the Rio Bonito Formation: Triunfo (base), Paraguaçu (intermediate) and Siderópolis (top). According to those authors, in the State of Paraná, the thickness of the Rio Bonito Formation decreases northwards, mainly because of the thinning and wedging out of the Triunfo Member, which disappears at the south of the State of São Paulo.

Soares \& Cava (1982) concluded that the most extensive peat formation event, located in the northern area of the Paraná State, was associated to deltaic plain environments correlative to the upper part of the Triunfo Member and at the base of Paraguaçu Member. Morrone \& Daemon (1985) and Della Fávera et al. (1994) agreed with these inferences.

According to Zacharias \& Assine (2005), different facies associations from the Rio Bonito Formation in the northeast of the Paraná State result from sedimentation on an irregular depositional surface. Peat swamps, of restricted occurrence, developed in paleoenvironments related to delta plains in the central portion of the estuary and were included in the basal part of the Paraguaçu Member.

The coal seam in Figueira Coalfield occurs on average at $40 \mathrm{~m}$ depth and is subdivided into a lower seam ( $0.4 \mathrm{~m}$ thick) and an upper seam ( $0.2 \mathrm{~m}$ thick) separated by a silty-sandstone layer of approximately $0.4 \mathrm{~m}$ thickness (Levandowski \& Kalkreuth, 2009).

Palynological data are not available for Figueira Coalfield. The only results concerning microfloristic analyses were registered by Ricardi-Branco et al. (2002), who identified megaspores of the genera Lagenoisporites, Sublagenicula and Setosisporites, of botanical affinity with arborescent lycophytes from siltstones immediately overlying the coal bed.

The Figueira paleoflora, recovered from siltsone layers interbedded with coal seams in different outcrops, was categorized by Ricardi-Branco \& Rösler (2004) under the following plant communities: swamp community [Brasilodendron cf. B. pedroanum (Carruthers) Chaloner, Leistikov \& Hill and Paracalamites australis Rigby]; flood plain community [Sphenophyllum brasiliensis Rösler, Annularia occidentalis Rösler, Asterotheca derbyi Rösler, Pecopteris cambuyensis (Read) Rösler, Sphenopteris lobifolia Morris and Glossopteris communis Feistmantel] and elevated terrain community (Paranocladus dusenii Florin and Paranospermum cambuiense Ricardi-Branco). Using coal petrography techniques Sbaraini (2006) inferred that the peatforming flora was composed mainly by arborescent plants, developed in transitional paleoenvironment controlled by fluvial and tidal processes.

Based on sequence stratigraphy, Holz et al. (2010) proposed a chronostratigraphic chart (Figure 2) for the Paraná Basin in which the Rio Bonito succession is included in two third order sequences. In relation to previous studies, this chart presents a new stratigraphic model for peat generation at northeastern and southern regions of the basin. The Siderópolis Member and its coal seams in Santa Catarina and Paraná States are linked to the Late Paleozoic Third-Order Sequence (LPTS) number 4 (Artinskian); in Rio Grande do Sul State, the Rio Bonito Formation is not formally subdivided into different lithostratigraphic members and the coal seams are included in the underlying LPTS-3 (Sakmarian). This new stratigraphic model is adopted in the present study. 


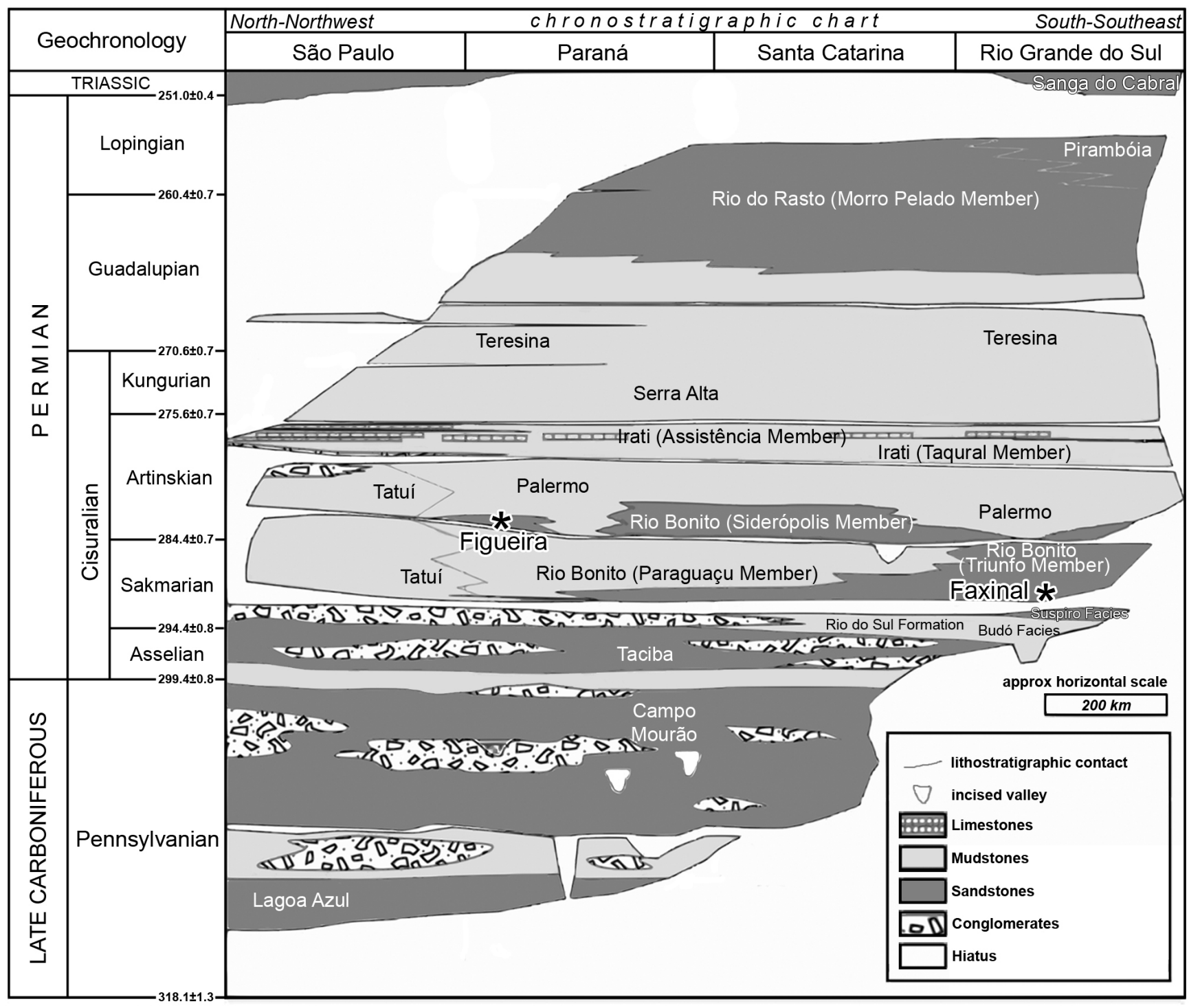

Figure 2. Simplified chronostratigraphic chart of the Late Carboniferous/Permian succession of the eastern border of the Paraná Basin indicating the approximate position of the Faxinal and Figueira Coalfields (modified from Holz et al., 2010). Stratigraphic position of the Faxinal Coalfield is based on radiometric age determination according to Guerra-Sommer et al. (2008b). Stratigraphic position of the Figueira Coalfield is based on sequence stratigraphy according to Holz et al. (2010).

\section{MATERIAL AND METHODS}

\section{Material}

Numerous leaves of Glossopteris occur haphazardly in different fossiliferous layers of the slabs. Most of the compressions are fragments of the detached leaves and some of them correspond to leaves organically attached to short shoots in whorls (Guerra-Sommer, 1988). Selected leaves are oblong to lanceolate in shape, with entire margins, midrib extends from the base (when present) to the apex and veins are a little arched.

The re-examination of the material described by Fittipaldi \& Rösler (1985) and Guerra-Sommer (1992) indicates that assemblages from Figueira and Faxinal Coalfields show an overall similarity in regard to the epidermal micromorphology, particularly the stomatal complex and the clear delimitation of costal and intercostal zones on one of the leaf faces. However, the stomatal pattern of the Glossopteris communis leaves described by Fittipaldi \& Rösler (1985) for the Paraná State remained insufficiently known because their stomatal description was based on the sparse ones from the adaxial leaf surface and no stomatal counts were carried out.

Pant \& Gupta (1968) described small cuticular pieces of Glossopteris communis derived from macerated material showing polygonal to irregular-shaped cells with straight walls and gave an emended diagnosis of this species. However, only non-stomatiferous zones have been observed.

\section{Methods}

Cuticles were mechanically pulled out from the surface of the Glossopteris leaves preserved as large fragments on the rock matrix (Figure 3) with the help of dissecting needles and 

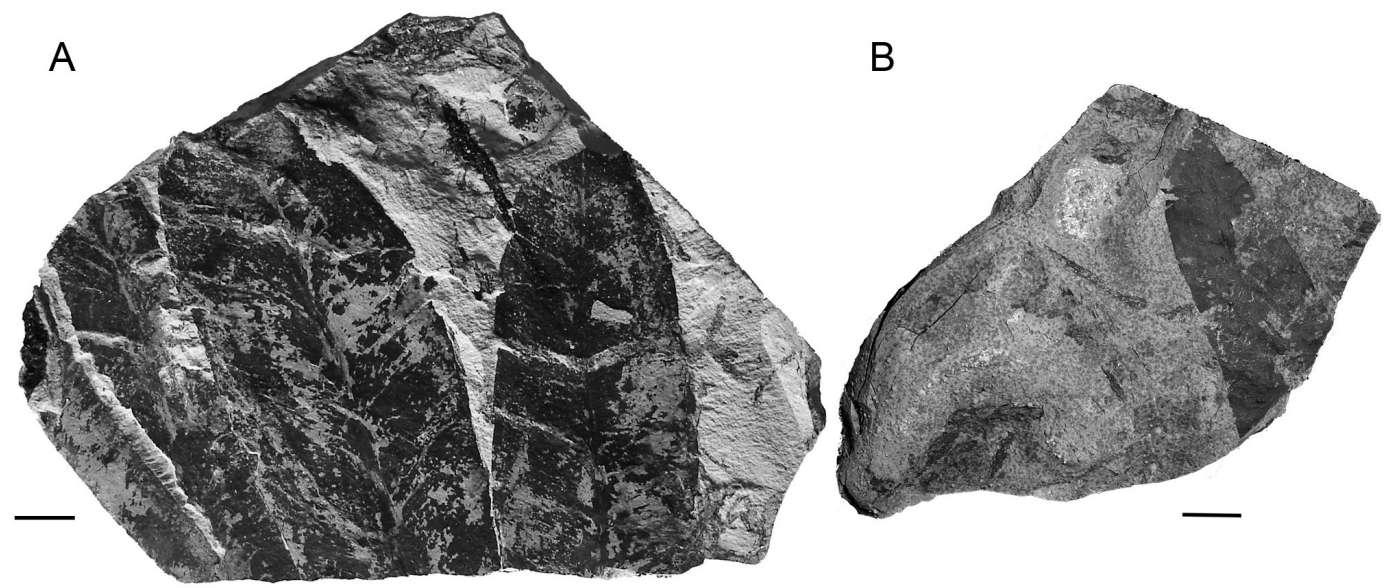

Figure 3. Rock slabs bearing compression specimens of Glossopteris leaves. A, tonstein slab from the Faxinal Coalfield stored in the paleobotanical collection of DPE-IG/UFRGS under the number PB4835; B, siltstone slab from the Figueira Coalfield housed in the collection of GSA-IGc/USP under the number GP/3E-6990. Scale bars $=2 \mathrm{~cm}$.

scalpel and then macerated in hydrofluoric acid for about 48 hours (Kerp, 1990). The dissolution of the rock allowed the cuticles to be released into the liquid and then to be filtered and gently washed in distilled water until neutralization.

Cuticles from Figueira Coalfield were sampled from a total of 11 leaf fragments. They were bleached with dilute Schulze solution for approximately 48 to 60 hours, using Fittipaldi \& Rösler's (1982) maceration process. After being washed with distilled water, the cuticles were treated with $10 \% \mathrm{KOH}$ for five minutes and then washed again.

The dilute Schulze solution was also employed in the preparation of the material from Faxinal Coalfield but it did not work. Then an alternative method derived by Gray (1965) was employed to make use of saturated dry Schulze solution ( $70 \% \mathrm{HNO}_{3}$ and $\mathrm{KClO}_{3} 7: 1$ ).

Cuticles from Faxinal Coalfield were sampled from a total of 59 leaf fragments. They were macerated with the dry Schulze solution for two hours, then gently washed and put in 5\% $\mathrm{KOH}$ solution for about five minutes and washed again with distilled water as per Kerp's procedure (1990).

All cuticles were dehydrated in pure glycerin (Krings \& Kerp, 1997) and mounted in glycerin jelly slides with the help of a stereoscopic microscope Leica S8 APO using incident and transmitted light under magnifications between 20x and 160x.

Slides were examined using a Zeiss Axioplan 2 microscope with Plan-Neofluar objectives and H/DIC II differential interference contrast filter (Kerp \& Krings, 1999). Pictures were taken using a Sony/Zeiss Cyber-shot DSC-S75 camera having 3.3 Megapixels at 400x magnification and the images were analyzed with the Zeiss Axio Vision 4.8.1 software.

Epidermal cells and stomata were counted and measured in the intercostal, stomatiferous zones. The stomatal density (SD) was determined by manually marking the number of stomata on the computer screen and dividing the result by the area value of the observed field to obtain the number per square millimeter (Salisbury, 1927).
The stomatal index (SI) was calculated using the formula SI $=100 S /(E+S)$ introduced by Salisbury (1927), where S represents the number of stomata and $\mathrm{E}$ the number of epidermal cells per unit area ( $c f$. Kerp, 1990). This formula expresses the stomatal numbers independently of the size of the epidermal cells in order to compensate for the effects of leaf expansion (Poole \& Kürschner, 1999). All cells were counted manually by marking them on the computer screen with the help of a software.

Data analysis was performed using the MULTIV 2.63 for Windows statistical software (Pillar, 2006). ANOVA with permutation tests (Pillar \& Orlóci, 1996) was employed to evaluate the effects of the factor 'site' (Faxinal $v s$. Figueira) on the stomatal results. Euclidean distances were used as dissimilarity index, and the sum of squares between groups ( $\mathrm{Qb}$ statistics) was used as test criterion (Legendre \& Legendre, 1998).

The fossils from Figueira Coalfield are housed at the collection of the Departamento de Geologia Sedimentar e Ambiental, Instituto de Geociências, Universidade de São Paulo (GSA-IGc/USP) under the code GP3E. The fossils from Faxinal Coalfield and all the slides prepared for this study are housed under the code PB at the collection of the Paleobotanical Section of the Departamento de Paleontologia e Estratigrafia, Instituto de Geociências, Universidade Federal do Rio Grande do Sul (DPE-IG/UFRGS), Porto Alegre, Brazil.

\section{RESULTS}

The material from Faxinal Coalfield yielded excellent slides and, from a total of 59 leaf fragments sampled, 43 cuticle fragments have been analyzed.

The cuticles from Figueira Coalfield were sampled from a total of 11 leaf fragments. However, only 5 fragments yielded well preserved cuticles to be useful for measurements and photographs. 
Epidermal cells were clearly visible in the Faxinal material (Figure 4), while in the Figueira cuticles the cell walls were not always preserved. Therefore, cell counts could not be obtained for the most part of Figueira material.

The adaxial leaf surface of Glossopteris communis is highly cutinized, mostly devoid of stomata and is composed of elongate, subrectangular cells. Papillae are absent from this surface. The abaxial epidermis is less cutinized, with elongated polygonal or subrectangular cells bearing a single papilla in the costal zones, while the cells of the intercostal zones consist mostly of subsidiary cells which are polygonal, sometimes subtriangular, subquadrangular, oval or irregularly shaped. Stomata of abaxial surface are haplocheilic and occur randomly oriented and sunken, with 4 to 8 (generally 5-7) subsidiary cells arranged in irregular rings, each bearing a prominent hollow papilla arching over the stomatal pore in the center. Subsidiary cells are sometimes shared between adjacent stomata (Figure 4).

The results of stomatal counts are given in table 1. Calculations for both SD and SI for the two stratigraphical levels indicate an increase of approximately $20 \%$ in stomatal numbers from the older (Sakmarian) to the younger (Artinskian) strata. Mean densities increased from $234.73 \mathrm{~mm}$ 2 in the Faxinal Coalfield to $284.14 \mathrm{~mm}^{-2}$ in the Figueira Coalfield, and indices increased respectively from 15.7 (mean) to 18.9. The trend in stomatal density observed in the Sakmarian to the Artinskian coalfields in the Rio Bonito Formation is represented in Figure 5.

SI calculation could be carried out on only one cuticle fragment from Figueira Coalfield and therefore statistical analysis could only be applied to the SD data.
The difference found for SD between the two sites is statistically significant, being $\mathrm{P}$ between groups $=0.0018$ (Table 2). The test applied is sufficiently robust and did not require data transformation, despite the sampling difference between the two sites in the data here presented (Pillar \& Orlóci, 1996).

Table 1. Calculation results of epidermal cell density (ED), stomatal density (SD) and stomatal index (SI). A, results for the Faxinal Coalfield (Sakmarian); B, results for the Figueira Coalfield (Artinskian). Abbreviations: NL, number of leaves sampled; NC, number of cuticle fragments analyzed; NE, number of epidermal cells counted; NS, number of stomata counted; n.a., not available.

\begin{tabular}{lccc}
\hline (A) Faxinal Coalfield (Sakmarian) & ED & SD & SI \\
\hline Mean & 1269.74 & 234.73 & 15.7 \\
Minimum & 977.68 & 160.78 & 12.6 \\
Maximum & 1779.03 & 328.06 & 18.75 \\
Standard deviation & 203.80 & 36.26 & 1.51 \\
Coefficient of variation $(\%)$ & 16.05 & 15.45 & 9.66 \\
\hline
\end{tabular}

$\mathrm{NL}=59 ; \mathrm{NC}=43 ; \mathrm{NE}=5355 ; \mathrm{NS}=992$

\begin{tabular}{lccc}
\hline (B) Figueira Coalfield (Artinskian) & ED & SD & SI \\
\hline Mean & 979.14 & 284.14 & 18.9 \\
Minimum & n.a. & 204.04 & n.a. \\
Maximum & n.a. & 481.26 & n.a. \\
Standard deviation & n.a. & 74.81 & n.a. \\
Coefficient of variation $(\%)$ & n.a. & 26.33 & n.a. \\
\hline
\end{tabular}

$\mathrm{NL}=5 ; \mathrm{NC}=17 ; \mathrm{NE}=90 ; \mathrm{NS}=355$

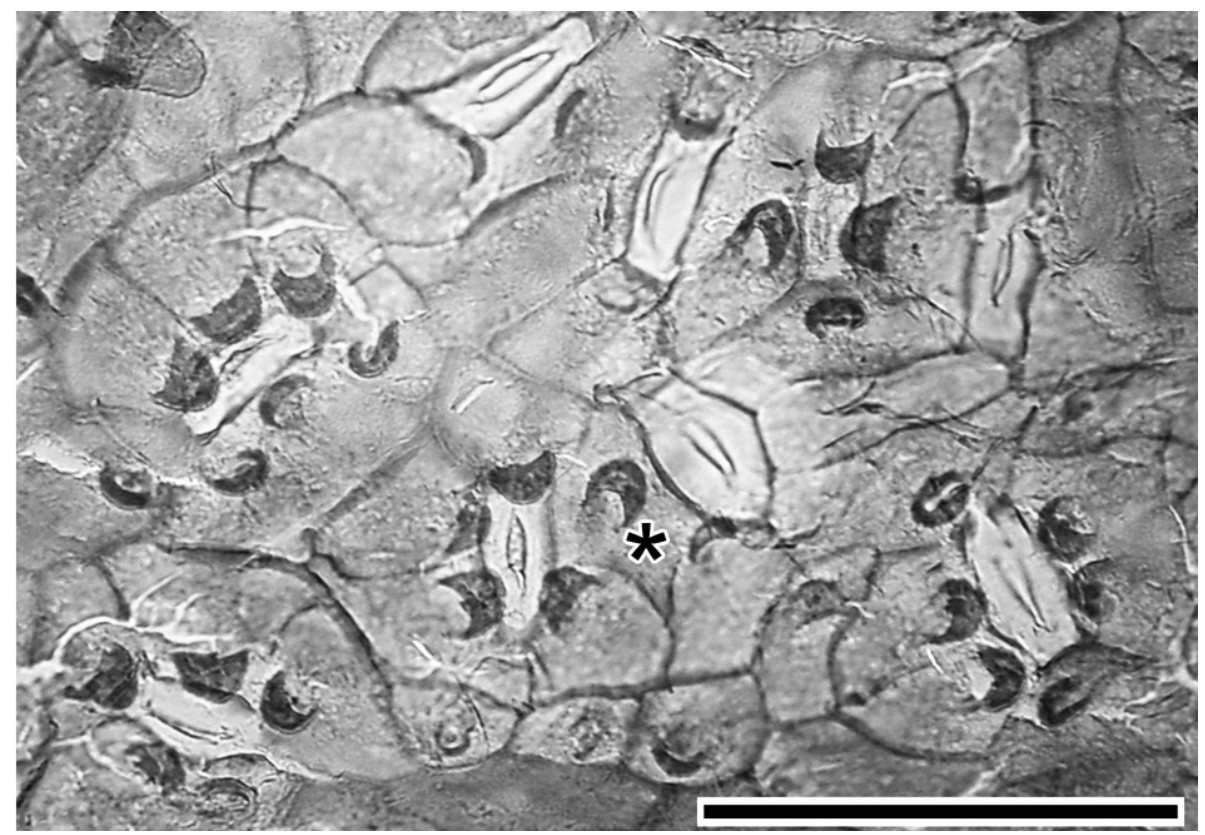

Figure 4. Transmitted light microscopy of the stomatal pattern in Glossopteris communis under 400x magnification. Stomatal apparatus is composed of 4-8 subsidiary cells, generally $5-7$, each bearing a hollow papilla which arches over the stomatal pore in the center. ${ }^{*}=$ note the subsidiary cell shared between two adjacent stomatal apparati. Slide of the Faxinal Coalfield material stored in the DPE-IG/UFRGS collection under the number PB4801-37-021. Scale bar $=100 \mu \mathrm{m}$. 


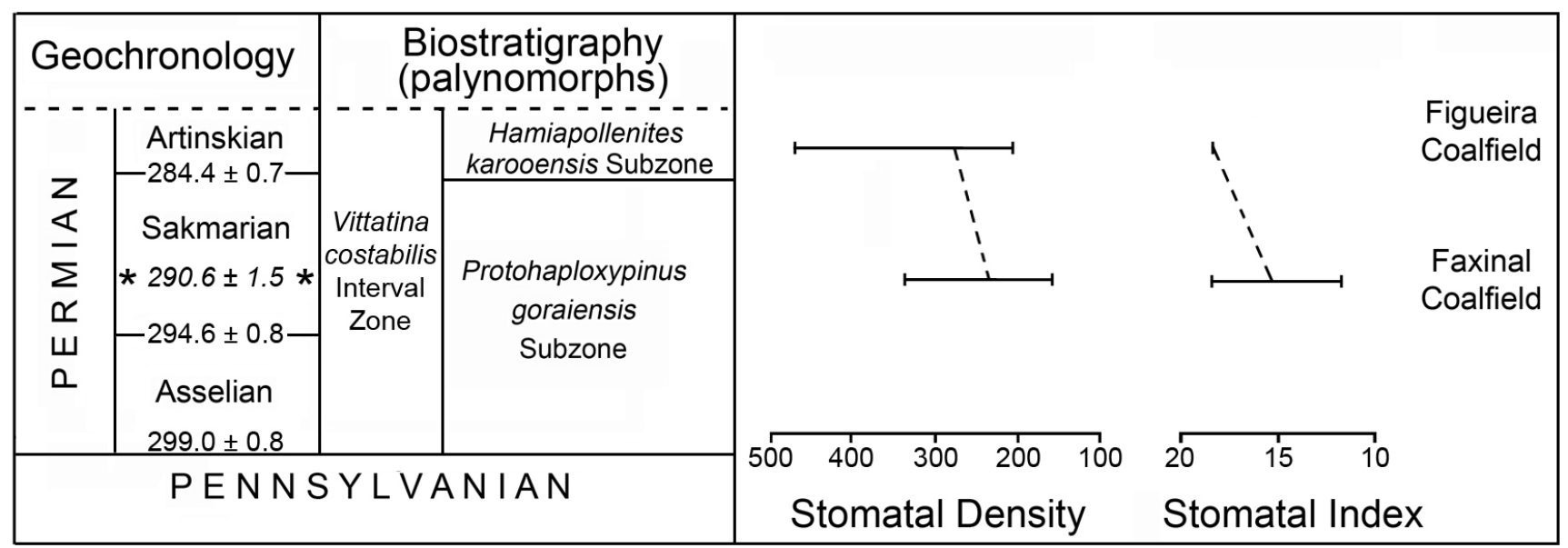

Figure 5. Trends in stomatal density and index in Glossopteris communis observed in the Sakmarian (Faxinal Coalfield) to Artinskian (Figueira Coalfield) of the Paraná Basin, Brazil (after Cleal et al., 1999). The Faxinal sample is shown against the absolute dating by Guerra-Sommer et al. (2008b). The Figueira sample is plotted according to data by Holz et al. (2010). The bar for each sample represents the total range in stomatal numbers observed, joined by the mean values through a dashed line. Stomatal index of Figueira samples is based on only one count.

Table 2. Results of ANOVA data analysis with permutation tests to evaluate the effects of the factor 'site' (Faxinal vs. Figueira) on the stomatal densities. ${ }^{*}=P$ probabilities generated for sum squares $(\mathrm{Qb})$, except for interactions, where $\mathrm{F}=\mathrm{Qb} / \mathrm{Qw}$ was employed as testing criterion.

\begin{tabular}{lcc}
\hline Source & Sum squares $(\mathrm{Q})$ & $P(\mathrm{QbNULL}>=\mathrm{Qb}) *$ \\
\hline $\begin{array}{l}\text { site } \\
\text { Between } \\
\text { groups }\end{array}$ & 29742 & 0.0018 \\
\hline
\end{tabular}

\section{DISCUSSION}

There are no published records that could be directly compared to the present results. Earlier studies by Pant \& Gupta (1968) for cuticular analyses in different species of Glossopteris from the Raniganj Coalfield, India (Wordian), do not include stomatal counts for G. communis, as did not the description by Fittipaldi \& Rösler (1985). Based exclusively on micromorphological features Guerra-Sommer (1992) described a new species for the Faxinal Coalfield, $G$. papillosa, which could be G. communis. Given that the specific epithet papillosa had already been employed to designate a Glossopteris species from India by Srivastava (1969), the designation by Guerra-Sommer (1992) is invalid.

Taking into account that Glossopteridales is an extinct group of plants with no living relatives or equivalents, this paper does not apply the transfer functions available for Ginkgo to SI values of Glossopteris communis. As a consequence, the data here obtained cannot be plotted on the curve modeled by Berner \& Kothavala GEOCARB III (2001) and Berner GEOCARBSULF (2006) for atmospheric $\mathrm{CO}_{2}$ variation in the Phanerozoic.

Thus, this study adopted the alternative approach given by Cleal et al. (1999) of comparing data of a single species from different fossil assemblages in similar paleoenvironments, but within distinct stratigraphic levels, to test the capability of detection of $\mathrm{CO}_{2}$ atmospheric fluctuations by Glossopteris communis.
According to Royer (2006), low levels of atmospheric $\mathrm{CO}_{2}$ are estimated for the Namurian-Kazanian interval. Different authors (Crowley \& Berner, 2001; Berner \& Kothavala, 2001; Royer et al., 2004) associated this event to an extensive Phanerozoic glaciation, suggesting strong coupling between $\mathrm{CO}_{2}$ and temperature. Isbell et al. (2003), instead of a continuous record of ice, argued for two shorter phases of glaciation. The coal interval from the Lower Permian of Paraná Basin can be associated with the termination of the second ice phase and was developed during a cool phase, from 290 until $267 \mathrm{Ma}$ (Royer, 2006).

The stomatal numbers obtained in Glossopteris communis can be confronted to those of the Early Permian conifer Lebachia frondosa (Renault) Florin. This species, among other taxa, was used by McElwain \& Chaloner (1995) to support the hypothesis that stomata parameters in fossil leaves would have potential value for detecting changes in the atmospheric $\mathrm{CO}_{2}$ concentration through geological time. The difference range between the stomatal numbers here calculated and of $L$. frondosa is narrow. Whereas mean SDs in G. communis vary between 234.73 and 284.14, in L. frondosa it corresponds to 309 . The mean SI values obtained for such a distinct species as a conifer (14.6) from the Tropical Summer Wet biome and glossopterid (15.7 to 18.9) from the Cool Temperate biome (sensu Rees et al., 2002) also display uniformity ( $c f$. Beerling \& Royer, 2002). A consistency is evidenced through the inferences of global low levels of atmospheric $\mathrm{CO}_{2}$ during the Lower Permian as predicted by the GEOCARB model (Berner, 1991, 1994; Berner \& Kothavala, 2001). On strictly northern hemisphere reconstructions published so far, this could be the first cross-check with southern hemisphere stomatal data as expected by Beerling \& Royer (2002).

Glossopteris communis in the Sakmarian has lower stomatal numbers than in the Artinskian, implying relatively higher levels of atmospheric $\mathrm{CO}_{2}$ during the former interval. Many factors could have influenced this trend. Considering the absolute age of $290.6 \pm 1.5 \mathrm{Ma}$ (Sakmarian) for the Faxinal 
Coalfield (Guerra-Sommer et al., 2008b) and the relative age of the Figueira Coalfield (Artinskian) according to the chronostratigraphic chart by Holz et al. (2010) for the Permian of Paraná Basin, a probable time span of about 8 Ma should have occurred between peat formation in the southern and the northeastern part of the basin. Additionally, the multiple coal seams (five or more), continuous and above one meter thickness registered at the Sakmarian southern coalfields are indicative of extensive peat accumulating swamps, generated in a barrier-lagoon depositional system, and found behind the barrier (Alves \& Ade, 1996; Holz et al., 2010). On the other hand, only one thin (about $0.6 \mathrm{~m}$ thick) and discontinuous coal bed is found in the northeastern part of the basin at the Artinskisan, formed in restricted peat swamp areas developed in saturated ambits of delta plain systems (Zacharias \& Assine, 2005). During the generation of peat mires in these northern areas, wetland forests were disappearing in the Brazilian Paraná Basin as indicated by palynostratigraphic data (Holz et al., 2010). An overall change in flora composition is marked by the transition of Vittatina costabillis Zone to the Luekisporites virkkiae palynozone right after the coal deposition of Figueira Coalfield attributed to climate change and tectonic activity (Holz et al., 2010).

A relation between the low stomatal numbers of Glossopteris communis in the Sakmarian (Faxinal Coalfield) of the southern Paraná Basin and the development of extensive mires can be inferred here. This important and extensive event of peat generation may have been sufficient to reverse regionally and temporarily the reduction trend in atmospheric $\mathrm{CO}_{2}$ according to the global curves established by the GEOCARB model (Berner \& Kothavala, 2001). Studies in present-day peatlands point out that this type of environment plays a significant role in the emission of greenhouse gases, especially under warming and flooding conditions (Billings et al., 1982; Aerts \& Ludwig, 1997; McKenzie et al., 1998). On the other hand, the younger peat mires developed in the northern areas of the basin were very sparse and therefore insufficient to affect the general low trend in atmospheric $\mathrm{CO}_{2}$.

It must also be observed that the integration of the results presented in this study with previously published data for the Faxinal Coalfield (Guerra-Sommer et al., 2008a; Jasper et al., 2009) allows us to infer that volcanic events could be identified as one of the potential sources of greenhouse gases.

According to Guerra-Sommer et al. (2008b), the volcanism detected in the southern Brazilian coal interval through the presence of tonstein layers was interpreted as the same which produced the Choiyoy Group in western Argentina (LópezGamundi, 2006). Nevertheless, unpublished data (J.O.S. Santos, pers. comm.) leads to the hypothesis that in the Brazilian region the explosive event occurred in still unidentified nearby areas.

\section{CONCLUSIONS}

Finer-scale patterns of atmospheric $\mathrm{CO}_{2}$ variations were detected for an $8 \mathrm{Ma}$ interval in the Lower Permian of the
Paraná Basin using stomatal parameters in Glossopteris communis leaves from two assemblages of different age intervals (Sakmarian and Artinskian).

The lower stomatal numbers have been observed at the climax of the peat deposition interval (Sakmarian) during a phase of globally estimated low paleoatmospheric $\mathrm{CO}_{2}$, and could be related to a temporary increase in $\mathrm{CO}_{2}$ levels due to extensive areas of peat accumulation and/or under intense ash fall due to volcanic activities.

The results show that the Permian taxon Glossopteris can be used as $\mathrm{CO}_{2}$-proxy. Although the evidence does not give direct results about the past atmosphere which could be compared to present-day levels, it does reveal fluctuations within the Sakmarian-Artinskian interval during the development of peat-forming systems in Brazilian sequences.

In order to corroborate the present results, future lines of investigation will include cuticular analyses of fossil plants from Permian coal-bearing strata from South Africa and India.

\section{ACKNOWLEDGEMENTS}

The authors wish to thank CPGq and CECO (IG/UFRGS) and the GSA-IGc/USP for their assistance and making available their facilities for the preparation and observation of the fossil material. This study was conducted during the tenure of a project funded by the Conselho Nacional de Desenvolvimento Científico e Tecnológico - CNPq (Project 471845/2007-8) and is submitted in partial fulfillment of the requirements for the M.S. degree at the Programa de PósGraduação em Geociências/UFRGS, Porto Alegre, Rio Grande do Sul (CNPq scholarship for IDS, process number 565586/ 2008-4). The authors are also grateful to B. Cariglino and K.J. Singh for reviewing the text.

\section{REFERENCES}

Aerts, R. \& Ludwig, F. 1997. Water-table changes and nutritional status affect trace gas emissions from laboratory columns of peatland soils. Soil Biology and Biochemistry, 29(11-12):16911698. doi:10.1016/S0038-0717(97)00074-6

Alves, R.G. \& Ade, M.V.B. 1996. Sequence stratigraphy and coal petrography applied to the Candiota Coal Field, Rio Grande do Sul, Brazil: a depositional model. International Journal of Coal Geology, 30(3):231-248. doi:10.1016/01665162(95)00041-0

Anderson, J.M. \& Anderson, H.M. 1985. The palaeoflora of southern Africa. Prodromus of South African megafloras Devonian to Cretaceous. Rotterdam, A.A. Balkema, 423 p.

Archangelsky, S.; Jalfin, G.A. \& Cúneo, N.R. 1996. Cuenca La Golondrina. In: S. Archangelsky (ed.) El Sistema Pérmico en la República Argentina y en la República Oriental del Uruguay, Academia Nacional de Ciencias, p. 93-108.

Banerjee, M. 2005. Autochthonous deposition of Indian coal beds with palaeobotanical evidences of in-situ plants from Saharjuri Basin, Jharkhand. Current Science, 88(9):1487-1490.

Beerling, D.J. 2002. Low atmospheric $\mathrm{CO}_{2}$ levels during the PermoCarboniferous glaciation inferred from fossil lycopsids. Proceedings of the National Academy of Sciences, 99(20):1256712571. doi:10.1073/pnas.202304999 
Beerling, D.J. \& Chaloner, W.G. 1992. Stomatal density as an indicator of atmospheric $\mathrm{CO}_{2}$ concentration. The Holocene, 2(1):71-78. doi:10.1177/095968369200200109

Beerling, D.J. \& Chaloner, W.G. 1993. Stomatal density responses of Egyptian Olea europaea L. leaves to $\mathrm{CO}_{2}$ change since 1327 BC. Annals of Botany, 71(5):431-435. doi:10.1006/ anbo.1993.1056

Beerling, D. J.; Fox, A. \& Anderson, C.W. 2009. Quantitative uncertainty analyses of ancient atmospheric $\mathrm{CO}_{2}$ estimates from fossil leaves. American Journal of Science, 309(9):775787. doi:10.2475/09.2009.01

Beerling, D.J. \& Royer, D.L. 2002. Fossil plants as indicators of the phanerozoic global carbon cycle. Annual Review of Earth and Planetary Sciences, 30:527-556. doi:10.1146/ annurev.earth.30.091201.141413

Berner, R.A. 1991. A model for atmospheric $\mathrm{CO}_{2}$ over Phanerozoic time. American Journal of Science, 291(4):339-376. doi:10.2475/ajs.291.4.339

Berner, R.A. 1994. GEOCARB-II - a revised model of atmospheric $\mathrm{CO}_{2}$ over Phanerozoic time. American Journal of Science, 294(1):56-91. doi:10.2475/ajs.294.1.56

Berner, R.A. 2006. GEOCARBSULF: a combined model for Phanerozoic atmospheric $\mathrm{O}_{2}$ and $\mathrm{CO}_{2}$. Geochimica et Cosmochimica Acta, 70(23):5653-5664. doi:10.1016/ j.gca.2005.11.032

Berner, R.A. \& Kothavala, Z. 2001. GEOCARB III: a revised model of atmospheric $\mathrm{CO}_{2}$ over Phanerozoic Time. American Journal of Science, 301(2):182-204. doi:10.2475/ajs.301.2.182

Billings, W.D.; Luken, J.O.; Mortensen, D.A. \& Peterson, K.M. 1982. Arctic tundra - a source or sink for atmospheric carbondioxide in a changing environment? Oecologia, 53(1):7-11. doi:10.1007/BF00377129

Cazzulo-Klepzig, M.; Guerra-Sommer, M.; Menegat, R.; Simas, M.W. \& Mendonça Filho, J. G. 2007. Peat-forming environment of Permian coal seams from the Faxinal Coalfield (Paraná Basin) in Southern Brazil, based on palynology and palaeobotany. Revista Brasileira de Paleontologia, 10(2):117-127.

Cazzulo-Klepzig, M.; Mendonça Filho, J.G.; Guerra-Sommer, M.; Menezes, T.R.; Simas, M. W., Mendonça, J.O. \& DeganiSchmidt, I. 2009. Effect of volcanic ash-fall on a Permian peatforming environment, on the basis of palynology, palynofacies and paleobotany (Faxinal Coalfield, Brazil). Revista Brasileira de Paleontologia, 12(3):179-194. doi:10.4072/rbp.2009.3.02

Chen, L.; Li, C.; Chaloner, W.G.; Beerling, D.J.; Sun, Q.; Collinson, M.E. \& Mitchell, P.L. 2001. Assessing the potential for the stomatal characters of extant and fossil Ginkgo leaves to signal atmospheric $\mathrm{CO}_{2}$ change. American Journal of Botany, 88(7):1309-1315.

Cleal, C.J.; James, R.M. \& Zodrow, E.L. 1999. Variation in stomatal density in the Late Carboniferous gymnosperm frond Neuropteris ovata. Palaios, 14(2):180-185.

Crowley, T.J. \& Berner, R.A. 2001. Paleoclimate - $\mathrm{CO}_{2}$ and climate change. Science, 292(5518):870-872.

Della Fávera, J.C.; Chaves, H.A.F.; Medeiros, M.A.M. \& Pereira, S.D. 1994. Eventos cíclicos do Permiano das áreas de Candiota (RS) e Figueira-Sapopema (PR). In: CONGRESSO BRASILEIRO DE GEOLOGIA, 38, 1994. Boletim de Resumos Expandidos, Camboriú, SBG, p. 594.

Fittipaldi, F.C. \& Rösler, O. 1982. Preparação de cutículas de plantas paleozóicas. Boletim IG-USP, 13:51-55.

Fittipaldi, F.C. \& Rösler, O. 1985. A cutícula de Glossopteris communis da Formação Rio Bonito no Estado do Paraná.
Brasília, Ministério das Minas e Energia, Departamento Nacional da Produção Mineral, p. 579-95 (Série Geologia 27/Seção Paleontologia e Estratigrafia 2).

Gastaldo, R.A.; DiMichele, W.A. \& Pfefferkorn, H.W. 1996. Out of the Icehouse into the Greenhouse: a late Paleozoic analog for modern global vegetational change. GSA Today, 6(10):1-7.

Gray, J. 1965. Extraction techniques. In: B. Kummel \& D. Raup (eds.) Handbook of paleontological techniques. San Francisco, W.H. Freeman, p. 530-586.

Guerra-Sommer, M. 1988. Padrões epidérmicos da Flora Glossopteris na Jazida do Faxinal (Formação Rio Bonito, Kunguriano, RS): implicações taxonômicas, bioestratigráficas, paleoecológicas e paleogeográficas. Curso de Pós-Graduação em Geociências, Universidade Federal do Rio Grande do Sul, Ph.D. thesis, $372 \mathrm{p}$.

Guerra-Sommer, M. 1992. Padrões epidérmicos de Glossopteridales da tafoflora do Faxinal (Formação Rio Bonito - ArtinskianoKunguriano, Bacia do Paraná, Brasil). Pesquisas em Geociências, 19(1):26-40.

Guerra-Sommer, M. \& Cazzulo-Klepzig, M. 2000. Permian palaeofloras from Southern Brazilian Gondwana: a palaeoclimatic approach. Revista Brasileira de Geociências, 30(3):486-491.

Guerra-Sommer, M.; Cazzulo-Klepzig, M.; Menegat, R.; Formoso, M.L.L.; Basei, M.A.S.; Barboza, E.G. \& Simas, M.W. 2008a. Geochronological data from the Faxinal coal succession, southern Paraná Basin, Brazil: a preliminary approach combining radiometric $\mathrm{U}-\mathrm{Pb}$ dating and palynostratigraphy. Journal of South American Earth Sciences, 25(2):246-256. doi:10.1016/ j.jsames.2007.06.007

Guerra-Sommer, M.; Cazzulo-Klepzig, M.; Santos, J.O.S.; Hartmann, L.A.; Ketzerc, J.M. \& Formoso, M.L.L. 2008 b. Radiometric age determination of tonsteins and stratigraphic constraints for the Lower Permian coal succession in southern Paraná Basin, Brazil. International Journal of Coal Geology, 74(1):13-27. doi:10.1016/j.jsames.2007.06.007

Guerra-Sommer, M.; Marques-Toigo, M. \& Silva, Z.C.C.1991. Original biomass and coal deposition in Southern Brazil (Lower Permian, Paraná Basin). Bulletin de la Société Géologique de France, 162(2):227-237.

Holz, M.; França, A.B.; Souza, P.A.; Iannuzzi, R. \& Rohn, R. 2010. A stratigraphic chart of the Late Carboniferous/Permian succession of the eastern border of the Parana Basin, Brazil, South America. Journal of South American Earth Sciences, 29(2):381-399. doi:10.1016/j.jsames.2009.04.004

Horbach, R.; Kuck, L.; Marimon, R.G.; Moreira, H.L.; Fuck, G.F.; Moreira, M.L.O.; Marimon, M.P.C.; Pires, J.L.; Vivian, O.; Marinho, D.A. \& Teixeira, W. 1986. Geologia. In: Projeto RADAM Brasil. Rio de Janeiro, Ministério das Minas e Energia, Instituto Brasileiro de Geografia e Estatística, 796 p. (Levantamento de Recursos Naturais 33).

Isbell, J.L.; Miller, M.F.; Wolfe, K.L. \& Lenaker, P.A. 2003. Timing of late Paleozoic glaciation in Gondwana: was glaciation responsible for the development of northern hemisphere cyclothems? In: M.A. Chan \& A.W. Archer (eds.) Extreme depositional environments: mega end members in geologic time. Boulder, Geological Society of America, p.5-24 (Special Paper 340).

Jasper, A.; Uhl, D.; Machado, N.T.G.; Gonçalves, C.V.; Guerra-Sommer, M. \& Cazzulo-Klepzig, M. 2009. Late Paleozoic wildfires in the South American part of the Gondwana Realm. In: INTERNATIONAL LATEINAMERIKA-KOLLOQUIUM, 21, 
2009. Abstracts and Program, Göttingen, Universitätsverlag, p. 146-147.

Kerp, H. 1990. The study of fossil gymnosperms by means of cuticular analysis. Palaios, 5(6):548-569.

Kerp, H. \& Krings, M. 1999. Light microscopy of cuticles. In: T.P. Jones \& N.P. Rowe (eds.) Fossil plants and spores: modern techniques. Geological Society, London, p. 52-56.

Kouwenberg, L.L.R.; McElwain, J.C.; Kurschner, W.M.; Wagner, F.; Beerling, D.J.; Mayle, F.E. \& Visscher H. 2003. Stomatal frequency adjustment of four conifer species to historical changes in atmospheric $\mathrm{CO}_{2}$. American Journal of Botany, 90(4):610-619. doi:10.3732/ajb.90.4.610

Krings, M. \& Kerp, H. 1997. An improved method for obtaining large pteridosperm cuticles. Review of Palaeobotany and Palynology, 96(3-4):453-456. doi:10.1016/S0034-6667(96)00059-0

Kürschner, W.M.; Stulen, I.; Wagner, F. \& Kuiper, P.J.C. 1998. Comparison of palaeobotanical observations with experimental data on the leaf anatomy of durmast oak [Quercus petraea (Fagaceae)] in response to environmental change. Annals of Botany, 81(5):657-664. doi:10.1006/anbo.1998.0605

Kürschner, W.M.; Van Der Burgh, J.; Visscher, H. \& Dilcher, D.L. 1996. Oak leaves as biosensors of late Neogene and early Pleistocene paleoatmospheric $\mathrm{CO}_{2}$ concentrations. Marine Micropaleontology, 27(1-4):299-312. doi:10.1016/03778398(95)00067-4

Legendre, P. \& Legendre, L. 1998. Numerical Ecology, $2^{\text {a }}$. ed. Amsterdam, Elsevier, 870 p.

Levandowski, J.H. \& Kalkreuth, W. 2009. Chemical and petrographical characterization of feed coal, fly ash and bottom ash from the Figueira Power Plant, Paraná, Brazil. International Journal of Coal Geology, 77(3-4):269-281. doi:10.1016/ j.coal.2008.05.005

López-Gamundi, O. 2006. Permian plate margin volcanism and tuffs in adjacent basins of west Gondwana: age constraints and common characteristics. Journal of South American Earth Sciences, 22(3-4):227-238. doi:10.1016/j.jsames.2006.09.012

McElwain, J.C. 1998. Do fossil plants signal palaeoatmospheric $\mathrm{CO}_{2}$ concentration in the geological past? Philosophical Transactions of the Royal Society of London, 353(1365):83-96. doi:10.1098/rstb.1998.0193

McElwain, J.C. 2003. Atmospheric carbon dioxide - stomata. In: D.E.G. Briggs \& P.R. Crowther (eds.) Palaeobiology II, Blackwell, p. 479-480.

McElwain, J.C.; Beerling, D.J. \& Woodward, F.I. 1999. Fossil plants and global warming at the Triassic-Jurassic boundary. Science, 285(5432):1386-1390. doi:10.1126/science.285.5432.1386

McElwain, J.C. \& Chaloner, W.G. 1995. Stomatal density and index of fossil plants track atmospheric carbon dioxide in the Palaeozoic. Annals of Botany, 76(4):389-395. doi:10.1006/anbo.1995.1112

McElwain, J.C. \& Chaloner, W.G. 1996. The fossil cuticle as a skeletal record of environmental change. Palaios, 11(4):376-388.

McKenzie, C.; Schiff, S.; Aravena, R., Kelly, C. \& Louis V.S. 1998. Effect of temperature on production of $\mathrm{CH}_{4}$ and $\mathrm{CO}_{2}$ from peat in a natural and flooded boreal forest wetland. Climatic Change, 40(2):247-266. doi:10.1023/A:1005416903368

Milani, E.J. 1997. Evolução tectono-estratigráûca da bacia do Paraná e seu relacionamento com a geodinâmica fanerozóica do Gondwana sul-oriental. Programa de Pós-graduação em Geociências, Universidade Federal do Rio Grande do Sul, Ph.D. thesis, 2 v., 255 p.

Morrone, N. \& Daemon, R.F. 1985. Jazida de Urânio de Figueira, Paraná. In: C. Schobbenhaus (ed.) Principais depósitos mine- rais do Brasil: recursos minerais energéticos, DNPM/CVRD, v. 1, p. 133-142.

Mosbrugger, V. 1999. The nearest living relative method. In: T.P. Jones \& N.P. Rowe (eds.) Fossil plants and spores: modern techniques. Geological Society, p. 261-265.

Pant, D.D. \& Gupta, K.L. 1968. Cuticular structure of some Indian Lower Gondwana species of Glossopteris Brongniart: part 1. Palaeontographica B, 124(1-3):45-81.

Pant, D.D. \& Gupta, K.L. 1971. Cuticular structure of some Indian Lower Gondwana species of Glossopteris Brongniart: part 2. Palaeontographica B, 132(1-4):130-152.

Pant, D.D. \& Singh, K.B. 1971. Cuticular structure of some Indian Lower Gondwana species of Glossopteris Brongniart: part 3. Palaeontographica B, 135(1-2):1-40.

Pigg, K.B. 1990. Anatomically preserved Glossopteris foliage from the central Transantarctic Mountains. Review of Palaeobotany and Palynology, 66(1-2):105-127. doi:10.1016/00346667(90)90030-M

Pigg, K.B. \& McLoughlin, S. 1997. Anatomically preserved Glossopteris leaves from the Bowen and Sydney basins, Australia. Review of Palaeobotany and Palynology, 97(3-4):339359. doi:10.1016/S0034-6667(97)00007-9

Pillar,V.D. 2006. MULTIV - Multivariate Exploratory Analysis, Randomization Testing and Bootstrap Resampling - User's Guide v.2.4. Departamento de Ecologia, UFRGS, Porto Alegre. Software and manual available at http://ecoqua.ecologia.ufrgs.br

Pillar, V.D. \& Orloci, L. 1996. On randomization testing in vegetation science: multifactor comparisons of relevé groups. Journal of Vegetation Science, 7(4):585-592. doi:10.2307/3236308

Poole, I. \& Kürschner, W.M. 1999. Stomatal density and index: the practice. In: T.P. Jones \& N.P. Rowe (eds.) Fossil plants and spores: modern techniques, Geological Society, p. 257-260.

Prevec, R.; Gastaldo, R.A.; Neveling, J.; Reid S.B. \& Looy, C. V. 2010. An autochthonous glossopterid flora with latest Permian palynomorphs and its depositional setting in the Dicynodon Assemblage Zone of the southern Karoo Basin, South Africa. Palaeogeography, Palaeoclimatology, Palaeoecology, 292(34):391-408. doi:10.1016/j.palaeo.2010.03.052

Prevec, R.; Labandeira, C.C.; Neveling, J. Gastaldo, R.A.; Looy, C.V. \& Bamford, M. 2009. Portrait of a Gondwanan ecosystem: a new late Permian fossil locality from KwaZulu-Natal, South Africa. Review of Palaeobotany and Palynology, 156(3-4):454493. doi:10.1016/j.revpalbo.2009.04.012

Rees, P.M., Ziegler A.M., Gibbs M.T., Kutzbach J.E., Behling P.J. \& Rowley D.B. 2002. Permian phytogeographic patterns and climate data/model comparisons. Journal of Geology, 110(1):131. doi: $10.1086 / 324203$

Retallack, G.J. 2001. A 300-million-year record of atmospheric carbon dioxide from fossil plant cuticles. Nature, 411(6835): 287-290. doi:10.1038/35077041

Ricardi-Branco, F.; Arai, M. \& Rösler, O. 2002. Megaspores from coals of the Triunfo Member, Rio Bonito Formation (Lower Permian), northeastern Paraná State, Brazil. Anais da Academia Brasileira de Ciências, 74(3):491-503. doi:10.1590/S000137652002000300011

Ricardi-Branco, F. \& Rösler, O. 2004. The paleoflora of Figueira in the context of neopaleozoic of Paraná Basin, Brasil. Terrae, 1(1):44-51.

Roth-Nebelsick, A. 2005. Reconstructing atmospheric carbon dioxide with stomata: possibilities and limitations of a botanical $\mathrm{pCO}_{2}$-sensor. Trees - Structure and Function, 19(3):251-265. doi:10.1007/s00468-004-0375-2 
Royer, D.L. 2006. $\mathrm{CO}_{2}$-forced climate thresholds during the Phanerozoic. Geochimica et Cosmochimica Acta, 70(23):56655675. doi:10.1016/j.gca.2005.11.031

Royer, D.L.; Berner, R.A. \& Beerling, D.J. 2001a. Phanerozoic atmospheric $\mathrm{CO}_{2}$ change: evaluating geochemical and paleobiological approaches. Earth-Science Reviews, 54(4):349392. doi:10.1016/S0012-8252(00)00042-8

Royer, D.L.; Wing, S.L.; Beerling, D.J.; Jolley, D.W.; Koch, P.L.; Hickey, L.J. \& Berner, R.A. 2001b. Paleobotanical evidence for near present-day levels of atmospheric $\mathrm{CO}_{2}$ during part of the Tertiary. Science, 292(5525):2310-2313. doi:10.1126/ science. 292.5525 .2310

Royer, D.L.; Berner, R.A.; Montañez, I.P.; Tabor, N.J. \& Beerling, D.J. 2004. $\mathrm{CO}_{2}$ as a primary driver of Phanerozoic climate. GSA Today, 14(3):4-10. doi:10.1130/10525173(2004)014<4:CAAPDO >2.0.CO;2.

Salisbury, E.J. 1927. On the causes and ecological significance of stomatal frequency, with special reference to the woodland flora. Philosophical Transactions of the Royal Society B, 431(256): 1-65.

Santos, R.V.; Souza, P.A.; Alvarenga, C.J.S.; Dantas, E.L.; Pimentel, M.M.; Oliveira, C.G. \& Araújo, L.M. 2006. Shrimp U-Pb zircon dating and palynology of bentonitic layers from the Permian Irati Formation, Paraná Basin, Brazil. Gondwana Research, 9(4):456-463. doi:10.1016/j.gr.2005.12.001

Sbaraini, E. 2006. Contribuição à interpretação paleoambiental dos depósitos de carvão do município de Figueira-PR, através da integração de dados petrográficos e estratigráficos. Programa de Pós-graduação em Geociências, Universidade Federal do Rio Grande do Sul, M.Sc. thesis, 55 p.

Schneider, R.L.; Mühlmann, H.; Tommasi, E.; Medeiros, R.A.; Daemon, R.F. \& Nogueira, A.A. 1974. Revisão estratigráfica da bacia do Paraná. In: CONGRESSO BRASILEIRO DE GEOLOGIA, 28, 1974. Anais, Porto Alegre, SBG, v. 1, p. 41-65.

Simas, M.W. 2008. Origem vulcânica para o tonstein da jazida do Faxinal (RS): estudos mineralógicos, petrográficos e de palinofácies. Programa de Pós-Graduação em Geociências, Universidade Federal do Rio Grande do Sul, M.Sc. thesis, 45 p.

Soares, P.C. \& Cava, L.T. 1982. Faciologia e potencial carbonífero da Formação Rio Bonito no Norte do Estado do Paraná. In: CONGRESSO BRASILEIRO DE GEOLOGIA, 32, 1982. Anais, Salvador, SBG, v. 3, p. 1120-1128.

Srivastava, A.K. 1997. Late Palaeozoic floral succession in India. In:
INTERNATIONAL CONGRESS ON THE CARBONIFEROUS AND PERMIAN, 13, 1995. Proceedings, Cracow, Polish Geological Institute, p. 269-272.

Srivastava, S.C. 1969. Two new species of Glossopteris from the Triassic of Nidpur, Madhya Pradesh, India. In: H. Santapau (ed.) J. Sen Memorial Volume, J. Sen Memorial Committee and Botanical Society of Bengal, p. 299-303.

Stewart, W.N. \& Rothwell, G.W. 1993. Paleobotany and the evolution of plants. $2^{\mathrm{a}}$ ed. Cambridge, University Press, $521 \mathrm{p}$.

Taylor, T.N.; Taylor, E.L. \& Krings, M. 2009. Paleobotany: the biology and evolution of fossil plants. $2^{\mathrm{a}}$ ed. Burlington, Academic Press, 1230 p.

Tichá, I. 1982. Photosynthetic characteristics during ontogenesis of leaves 7: stomata density and sizes. Photosynthetica, 16(3):375-471.

Van Der Burgh, J.; Visscher, H.; Dilcher, D.L. \& Kürschner, W.M. 1993. Paleoatmospheric signatures in Neogene fossil leaves. Science, 260(5115):1788-1790. doi:10.1126/science.260.5115.1788

Vörding, B. \& Kerp, H. 2008. Stomatal indices of Peltaspermum martinsii (Pteridospermopsida, Peltaspermaceae) from the Upper Permian Bletterbach Gorge and their possible applicability as $\mathrm{CO}_{2}$ proxies. Neues Jahrbuch für Geologie und Paläontologie, Abhandlungen, 248(2):245-255. doi:10.1127/0077-7749/2008/0248-0245

Vörding, B.; Krings, M. \& Kerp, H. 2009. Reconstruction of Late Pennsylvanian $\mathrm{CO}_{2}$ levels based on Odontopteris brardii (Pteridospermopsida, ?Medullosales) cuticles from France and Germany. Neues Jahrbuch für Geologie und Paläontologie, Abhandlungen, 254(3):359-372. doi:10.1127/0077-7749/2009/ 0024

Wagner, F.; Dilcher, D.L. \& Visscher, H. 2005. Stomatal frequency responses in hardwood-swamp vegetation from Florida during a 60-year continuous $\mathrm{CO}_{2}$ increase. American Journal of Botany, 92(4):690-695. doi:10.3732/ajb.92.4.690

Woodward, F.I. 1987. Stomatal numbers are sensitive to increases in $\mathrm{CO}_{2}$ from pre-industrial levels. Nature, 327(6123):617-618. doi: $10.1038 / 327617 a 0$

Zacharias, A.A. \& Assine, M.L. 2005. Modelo de preenchimento de vales incisos por associações de fácies estuarinas, Formação Rio Bonito no norte do estado do Paraná. Revista Brasileira de Geociências, 35(4):573-583.

Received in August, 2010; accepted in April, 2011. 